\author{
ANNA KRASNODĘBSKa \\ UNIWERSYTET OPOLSKI \\ Instytut NAUK PEDAgogicZnYCH \\ E-MAIL: ANNA.KRASNODEBSKA@OP.PL
}

\title{
RELACJE OPOLSKICH MIGRANTEK ZAROBKOWYCH Z PRACODAWCAMI I RODZINĄ
}

\section{Wstęp}

W rozstrzyganiu problematyki rodziny dostrzega się zmiany, jakie dotyczą sposobu odnoszenia się do pojęcia rodzina i jej funkcjonowania. Dyskutuje się na temat procesu tworzenia się rodzin (małżeństwo, kohabitacja, związki typu Living-Apart-Together) i rozwiązywania (rozwody, separacje) oraz problemu dzietności. Coraz częściej podkreśla się rolę przemian kulturowych przyczyniających się do większej społecznej akceptacji modelu rodziny z obojgiem rodziców pracujących w pełnym wymiarze. Częściej też w naukach społecznych mamy do czynienia z odwoływaniem się do kwestii łączenia przez kobiety obowiązków rodzinnych i zawodowych. Widoczny rosnący udział kobiet w rynku pracy, ich aktywność zawodowa jest nieodwracalnym procesem, któremu towarzyszy zmiana ról społecznych i systemu wartości. Można wręcz mówić o potrzebie łączenia w sposób harmonijny pracy zawodowej i życia osobistego (work-life-balance).

Potrzeba bycia aktywną w obszarze pracy i zaspokajania potrzeb rodziny powoduje, że kobiety coraz częściej migrują. Wyruszają w nowe miejsca, do nowej pracy, także poza granice kraju. Jest to dla wielu $z$ nich swego rodzaju wyzwanie, a równocześnie nowe, ekscytujące przeżycie. Często ma miejsce próba zrozumienia obcych kultur przez relacje z ludźmi, którzy ją reprezentują [Bjerke 2004: 9]. Decyzje migracyjne są determinowane życiowymi sytuacjami kobiet i przyczyniają się do zdobywania przez nie nowych doświadczeń nie tylko w obszarze pracy. Znaczenie mają dokonujące się przemiany społeczne: „nowe prądy, idee i zmieniające się globalne rynki pracy wypychają masowo kobiety $\mathrm{z}$ orbis interior, lokując je także poza tradycyjnymi formami życia 
społeczeństwa (głównie domem i rodziną), i kreując nowe sposoby myślenia oraz określania swej tożsamości”[Slany 2008: 9].

W badaniach migracyjnych zauważa się, że są regiony, gdzie z dużą siłą występuje zjawisko migracji, powodowane przez wysokie bezrobocie i niewielkie szanse na zatrudnienie czy zarobkowanie. Do takich może być zaliczana Opolszczyzna, która współcześnie charakteryzuje się jednym z najwyższych wskaźników migracji zarobkowych krótkoterminowych. Warto także zwrócić uwagę na to, że skłonność mieszkańców tego regionu do migracji ma także swoje historyczne i społeczno-polityczne uwarunkowania. Na Opolszczyźnie od lat istnieją silnie rozwinięte sieci powiązań migracyjnych, obejmujące społeczności lokalne i skupiska migrantów z tych społeczności. Nadal odgrywają one ogromną rolę w kreowaniu strumieni migracyjnych. Znaczącą rolę mają sieci rodzinne, ale też przyjaciele, znajomi, koledzy, byli mieszkańcy regionu mocno zakorzenieni $\mathrm{w}$ nowym kraju, którzy podtrzymują więź z miejscem pochodzenia i wspierają kolejnych migrantów. W innych regionach też funkcjonują takie sieci, ale nie są one tak ukształtowane i wszechstronne jak na Śląsku Opolskim. Nowa, poakcesyjna migracja w województwie opolskim jest i będzie uzależniona od aspektów aspiracyjnych i strukturalno-edukacyjnych. W najbliższych latach czynniki przyciągające za granicę mogą nadal oddziaływać. Znaczące będą te wypychające. „Ma to swój wyraz w strukturze bezrobocia: koniunkturalnego, strukturalnego, agrarnego, masowego, ukrytego i frykcyjnego Aktualnie bezrobocie jawne przekroczyło 45 tysięcy osób i charakteryzuje się głębokim zróżnicowaniem przestrzennym. Kryzys ekonomiczny, szczególnie dużych i średnich przedsiębiorstw w województwie opolskim, $\mathrm{w}$ powiązaniu $\mathrm{z}$ rosnącą podażą młodzieży wchodzącej na rynek pracy w latach 2000-2010, charakteryzuje się wysokim bezrobociem oraz masową migracją zarobkową ludności, która wyraźnie ogranicza bezrobocie w województwie" [Rauziński, Szczygielski 2010: 57].

Ograniczenie bezrobocia przez migracje nie oznacza, że ma miejsce jednoczesny wzrost zatrudnienia i aktywności gospodarczej. Migracja powoduje odpływ pracowników określonych specjalności. Sytuacja ta może niekorzystnie wpływać na rozwój małych i średnich przedsiębiorstw, które w sytuacji utrzymywania się wzmożonych wyjazdów zagranicznych tracą możliwości działania i rozwoju [Krasnodębska 2009a: 50-53]. Zauważa się, że migracja zarobkowa w województwie opolskim przyczynia się do zwiększenia dochodów ludności i poprawy sytuacji materialnej opolskich rodzin [Program 2007]. Powoduje jednak osłabienie więzi rodzinnych i społecznych [Krasnodębska 2008b: 75-79; Krasnodębska 2013a: 162-175]. Narastają dysproporcje w warunkach i poziomie życia ludności o różnym pochodzeniu regionalnym. Odpływ wy- 
kwalifikowanych kadr do pracy za granicą osłabia potencjał ekonomiczny i społeczny miasta, a w dalszej perspektywie przekłada się na tempo procesów rozwojowych. Wielu migrantów deklaruje chęć pozostania na dłuższy czas lub na stałe za granicą. Jeżeli zdecydują się na powrót, to wtedy, gdy zmieni się sytuacja ekonomiczna, będzie dostęp do bogatszej oferty miejsc pracy, pojawią się możliwości awansu i lepsze zarobki umożliwiające odpowiedni poziom oraz komfort życia [Program 2007].

Interesujące dla pokazania specyfiki opolskiego regionu są wnioski z badań przeprowadzonych przez Romualda Jończego, w których została wyłoniona grupa emigrantów definitywnych, którzy przebywają za granicą na stałe od przynajmniej kilku lat, ale nie wymeldowali się z miejsca zamieszkania w Polsce [Jończy 2010]. Grupę tę tworzą przede wszystkim Ślązacy autochtoni w liczbie co najmniej 90 tys. osób nadal zameldowanych na terenie województwa opolskiego. Autor nazywa ich migrację emigracja zawieszoną, która na terenie, gdzie jest rejestrowane zjawisko powoduje duże rozbieżności między danymi meldunkowymi a faktyczną liczba mieszkańców, sięgające w niektórych miejscowościach nawet $45 \%$, a ok. $30 \%$ w wybranych gminach. O takim zawieszeniu świadczą najnowsze badania prowadzone w środowisku migrantów. Badani za pomocą internetowego narzędzia podkreślali, że ich wyjazd spowodowany przede wszystkim czynnikami materialnymi, potrzebą znalezienia pracy stał się niejednokrotnie powodem do pozostania na stałe w kraju migracji. Dla respondentów znaczący był charakter wykonywanej pracy, stopień zadowolenia z tego, co ma miejsce w obszarze zawodowym, relacje z innymi (zarówno rodakami, jak i mieszkańcami kraju przyjmującego).

Praca jest traktowana jako świadoma działalność ludzka ważna ze społecznego punktu widzenia. Jej celem jest zaspokojenie potrzeb mających społeczne znaczenie, zapewnienie jednostkom i grupom ludzkim, które ją wykonują określonej pozycji w społeczeństwie. Dostrzega się także jej wychowawcze znaczenie. Jest ona podstawową wartością dla współczesnego człowieka, która przekształca otaczający go świat i jego samego. Ma wpływ na rozwój człowieka i jego stosunek do pracy. To w obszarze pracy jednostki i grupy ludzkie uczą się współpracy i współdziałania. Praca staje się nie tylko źródłem zarobkowania, ale również możliwością samorealizacji. Dlatego ważne jest rozpoznawanie, w jaki sposób ludzie ustosunkowują się do niej i jak oceniają relacje międzyludzkie pojawiające się w obszarze pracy. Istotne jest również to, w jaki sposób zaangażowanie w pracę przekłada się na życie rodzinne. Ważna jest także sytuacja kobiet na rynku pracy. Jest wiele dysproporcji w statusie zawodowym ze względu na płeć. Dotyczą one niższej od mężczyzn aktywności zawodowej i niższego zatrudnienia. To kobiety stanowią wyższy odsetek długotrwale bezrobotnych. 
Mimo porównywalnego z mężczyznami poziomu wykształcenia kobiety otrzymują niższe zarobki. Z rynku pracy mogą je eliminować obowiązki domowe (w tym wychowanie dzieci), [Sztanderska 2006: 4]. Problemem jest też wiek pracownika. Wskaźnikiem obrazującym sytuacje osób starszych na rynku pracy jest aktywność zawodowa, czyli gotowość do podjęcia pracy. Tutaj też pojawiają się różnice ze względu na płeć. Aktywność zawodowa osób w wieku przedemerytalnym wynosi w przypadku mężczyzn 40\% (w stosunku do 64\% ogółu osób aktywnych zawodowo) i 20\% wśród kobiet (wobec 50\% ogółu), [Schimanek 2006: 5]. Na regionalnym rynku pracy w województwie opolskim od końca grudnia 2005 do końca grudnia 2012 odnotowano wzrost liczby bezrobotnych powyżej 50. roku życia [Kalski, Nieroba, Muster 2013: 27]. Bezrobocie w województwie opolskim częściej dotyczy kobiet niż mężczyzn.

W przypadku kobiet pracujących za granicą można mówić o tym, że nowa rzeczywistość stawia przed nimi szczególne wyzwania. Dla wielu z nich kraj migracji oferuje miejsca pracy, daje możliwość bycia aktywną zawodowo. Migrantkom towarzyszy jednak element ryzyka. Ryzyko jest już wpisane w samą aktywność, jaką jest ich mobilność. Zdają się one bagatelizować ryzyko pracy za granicą i różny jej charakter, bo pozostanie w kraju też niesie za sobą zagrożenie dla nich i ich rodzin. Nie zawsze ich decyzje spotykają się ze społeczną aprobatą. Zagraniczne wyjazdy migracyjne traktuje się jako zagrożenie dla modelu rodziny i oczekiwanego społecznego wzorca macierzyństwa [Urbańska 2008: 83].

\section{Opis badań}

Podstawą do refleksji na temat relacji migrantek w obszarze pracy i rodziny są badania ilościowe i jakościowe prowadzone wśród kobiet z Opolszczyzny pracujących zarobkowo poza granicami kraju. W swoim tekście odnoszę się do wybranych fragmentów wywiadów, jakie w 2007 i 2008 roku prowadziłam w środowisku zarobkowo migrujących kobiet z regionu Opolszczyzny (ponad 60 wywiadów) oraz listów i pamiętników oddających pełnię wrażeń, odczuć i refleksje opolskich migrantek (30 listów), [Krasnodębska 2009b: 251-172; Krasnodębska 2013b: 85-103]. Wywiady narracyjne trwające od 1 do 3 godzin były nagrywane, a następnie zapisywane z zachowaniem oryginalnej wypowiedzi, którą zaprezentowano w przedstawianym tekście. Rozmówczynie, to osoby między 18 a 65 rokiem życia, z przewagą młodych osób (42 osoby - 18-29 lat; 18 osób - 30-49 lat; 9 osób - 50-65 lat). Listy to pisemne relacje kobiet, 
które w 2007 roku zgłosiły się do konkursu, ogłoszonego w regionalnej gazecie („Nowa Trybuna Opolska”), na wspomnienia z pracy za granicą. Konkurs był anonimowy i dlatego trudno określić dane społeczno-demograficzne uczestniczek. Jedynie treść i sposób wypowiedzi autorek listów sugerowały ich wiek, wykształcenie. W rezultacie trzydzieści kobiet przesłało na adres gazety swoje wspomnienia. Te opisy i bardzo osobiste relacje badanych kobiet będą wzbogacone o wyniki wieloaspektowych badań kwestionariuszowych, w których dobrane zostały dwie grupy kobiet: migrujące 357 osób (w tej kategorii osób pojawiły się te, które jeździły do pracy za granicą, są w trakcie lub mają zamiar wyjechać) i niemigrujące - 164 (nie miały wcześniej doświadczeń migracyjnych i nie mają zamiaru wyjeżdżać zarobkowo poza granice naszego kraju). Kwestionariusz zawierał 44 pytania dotyczące kwestii związanych z sytuacją przedmigracyjną kobiet; dotyczące motywów i oczekiwań związanych z migracją; zastanej rzeczywistości migracyjnej (praca, nowi ludzie, otoczenie) i sposobów funkcjonowania w niej oraz skutków, jakie niesie dla kobiet i ich najbliższych (rodziny, dzieci). W ramach kwestionariusza zastosowane zostały pytania otwarte, półotwarte, $z$ mocno rozbudowaną kafeterią odpowiedzi, i pytania zamknięte ze skalą dychotomiczną (tak, nie) lub pięciostopniową skalą Likerta. Pojawiło się również 16 pytań pozwalających poznać dane społeczno-demograficzne badanych kobiet.

W badaniach wykorzystujących kwestionariusz próbę kwotową dobrano przez określenie cech społeczno-demograficznych dla ośmiu wybranych powiatów z terenu Opolszczyzny. Wzięto pod uwagę te powiaty, w których odsetek migrujących jest najwyższy w stosunku do liczby ludności i te, w których jest najniższy. Te pierwsze w większości zamieszkałe przez ludność historycznie związaną z tym regionem (autochtoniczną) - powiaty: strzelecki, krapkowicki, oleski, kędzierzyńsko-kozielski. Drugie natomiast są zamieszkane przez dużą liczbę ludności napływowej - powiaty: nyski, brzeski, namysłowski. W badaniach tych uczestniczyły kobiety w wieku $18-65$ lat (22,8\% - 18-28 lat, 22,8\% - 29-37 lat, 23,2\% - 38-48 lat, 23,2\% - osoby powyżej 49 roku życia). Badane kobiety to osoby $\mathrm{z}$ różnym wykształceniem będące $\mathrm{w}$ odmiennej sytuacji społeczno-ekonomicznej. Przeważały kobiety z wykształceniem zasadniczym zawodowym $(49,71 \%)$, średnim $(23,61 \%)$, podstawowym $(16,51 \%)$ wyższym $(6,91 \%)$, studia pomaturalne $(2,88 \%)$. W grupie badanych kobiet najczęściej pojawiały się mężatki $(60,27 \%)$, ale były także rozwódki, wdowy oraz niezamężne kobiety, które czasami ponosiły samotnie ciężar utrzymania rodziny.

W badaniach jakościowych i kwestionariuszowych uczestniczyły kobiety, które jeździły głównie do Niemiec, Holandii i Anglii. W większości stanowiły one kategorię migrantek w ruchu. Pracowały za granicą 2-3 miesiące, a potem, 
kiedy przyjeżdżały na krótko do kraju, ich miejsce zajmowała zmienniczka. Przejawiały postawy, dążenia charakteryzujące polskich migrantów jako „ludzi na huśtawce", a więc osoby, które zarabiają za granicą, wracają do kraju, a po wyczerpaniu zarobionych zasobów finansowych ponownie wyjeżdżają do pracy, aby rozpocząć nowy cykl wyjazdu i powrotu. Wiele z tych opolskich migrantek podobnie, jak to stwierdza Marek Okólski, wykorzystywało zasadę huśtawki wielokrotnie [Okólski 2001:9-61]. W badanej próbie znalazła się również mniej liczna grupa kobiet, która poza granicami kraju spędzała dłuższy czas - nawet kilka lat. Kobiety pracowały głównie w sektorze usług opiekuńczo-domowych, rolno-ogrodniczym (pracownice sezonowe) czy przy tak zwanej taśmie w firmach przetwórczych oraz w turystyce. Wśród badanych były kobiety, które podjęły pracę w sektorze usług domowych wykonując prace na rzecz gospodarstwa domowego, a także opiekując się dziećmi lub osobami starszymi. Badane kobiety najłatwiej znajdowały zatrudnienie w obszarze pracy fizycznej, niżej płatnej, niewymagającej wyjątkowych kwalifikacji.

$\mathrm{W}$ badaniach przyjęto następujące zasady poruszania się $\mathrm{w}$ terenie $\mathrm{w}$ trakcie realizacji badań . Na wybranym osiedlu lub w wybranej wsi prowadzący badania przechodzili do co piątego gospodarstwa domowego i pytali o osobę wyjeżdżającą do pracy za granicą lub będącą na wyjeździe. Jeśli pojawiła się taka osoba, to realizowano z nią wywiad po wcześniejszym uzyskaniu od niej zgody na badania i ustaleniu terminu wywiadu lub pozostawiano kwestionariusz ankiety. Sprawdzano także ważne kryteria, jakie miała spełniać badana osoba, czyli wiek, wykształcenie, miejsce zamieszkania.

W prezentowanym tekście skoncentruję się na przedstawieniu jednego $\mathrm{z}$ aspektów migracji, związanego przede wszystkim $\mathrm{z}$ indywidualnym wymiarem badań tego zjawiska, czyli subiektywnego odczuwania doświadczenia migracji, w sferze pracy oraz życia rodzinnego. Spróbuję odpowiedzieć na pytania, jakie były przyczyny wyjazdów do pracy za granicą? W jaki sposób sytuacja rodzinna badanych kobiet przyczyniła się do ich wyjazdu za granicę? Jaki był stosunek badanych kobiet do pracy za granicą? Jak oceniały warunki swojej pracy i relacje z pracodawcami? W jaki sposób próbowały pogodzić pracę migracyjną $\mathrm{z}$ życiem rodzinnym? Jak oceniały relacje rodzinne w sytuacji rozstania migracyjnego?

\section{Motywy wyjazdu do pracy za granicą}

Niniejszy tekst dotyczy relacji migrantek z pracodawcami. Jednak to rodzina, potrzeba zapewnienia jej godnego funkcjonowania stawały się istotną przy- 
czyną podejmowania pracy za granicą przez opolskie kobiety. Materiał empiryczny pozwala sądzić, że kobiety: matki, babcie, córki wyjeżdżały do pracy za granicę, ponieważ:

- myślały o podstawowym zabezpieczeniu bytu swojej rodzinie;

- rzadko miały w Polsce stałą dobrze płatną pracę, często pracowały w niepełnym wymiarze godzin, trudnych warunkach pracy, dorywczo, za niskie wynagrodzenie lub wykonywały pracę poniżej swoich kwalifikacji; niektóre z nich pobierały niską rentę lub emeryturę;

- chciały przede wszystkim mieć lepiej płatną pracę, zarobić na własne mieszkania, spłacić zadłużenia w kraju, opłacić studia (swoje, dzieci), zabezpieczyć sobie i dzieciom przyszłość;

- dostrzegały wyjazd jako najlepsze, a czasami jedyne, rozwiązanie trudnej sytuacji rodzinnej i ochronę przed ubóstwem w kraju;

- nie zawsze mogły liczyć na konkretną pomoc ze strony bliskiego otoczenia, często samego męża, partnera; nie mogły liczyć na pomoc w sensie ekonomicznym, ale również emocjonalno-uczuciowym; dla niektórych kobiet istotnym powodem były zachowania, postawy małżonków; brak ich zaangażowania $\mathrm{w}$ życie rodzinne, brak chęci wspomagania rodziny, czy wręcz zdrady, odejście współmałżonka.

Krótka relacja młodej kobiety pokazuje całe spektrum powodów takiej mobilności: „I cóż miałam robić kobieta z dwójką dzieci na utrzymaniu, przed życiowym rozłamem małżeństwa, bez pracy i z półrocznym zasiłkiem” (List nr 27).

Badane kobiety niejednokrotnie mówiły o swoim życiu, o wcześniejszych losach, decydujących o ich wyjeździe do pracy za granicę. Pojawiały się w tych relacjach opisy ich rodzinnych, zawodowych, małżeńskich problemów i towarzyszących im emocji. Większość z nich podawała trudne ekonomiczne położenie ich samych, ich rodzin oraz bliskich osób. Szczególnie starsze kobiety, bez odpowiedniego wykształcenia, w swoim środowisku lokalnym, były pozbawione szansy na lepsze życie, czy wręcz środków na przetrwanie. „Mój minus był taki, że ja nie miałam studiów, gdybym miała, miałabym inną pozycję, miałabym pracę" (32 K 55) $)^{1}$ Każda z badanych kobiet decydując się na wyjazd kierowała się określonymi motywami, każdej towarzyszyły różnorodne emocje i uczucia.

Wyjeżdżały, bo w kraju nie mogły znaleźć pracy, utraciły ją lub ze względu na sytuację finansową zostały zmuszone do jej podjęcia: „Zaczęłam jeździć jak «padł» mój zakład pracy" (List nr 1).

$\overline{1}$ Wypowiedzi rozmówczyń zakodowano i tak 32- to numer wywiadu K-kobieta, 55- wiek 
Kobiety w sytuacji bycia bez pracy miały poczucie bycia gorszą, nie w pełni wartościową osobą: Nie miałam pracy po skończonym licencjacie, czułam się niepotrzebna (22 K 23).

Badane kobiety mogły dostrzegać pracę za granicą z punktu realizacji wartości, szans i możliwości, jakie stwarza ona jednostkom i grupom. Praca za granicą sprzyjała ich aktywności zawodowej i niezależności finansowej. Mogła zmienić ich pozycję społeczną, sposób rozumienia, co to znaczy być kobietą i móc realizować się $\mathrm{w}$ różnych rolach. Rozmowa $\mathrm{z}$ małżonkiem jednej z migrantek świadczyła, że o wyjeździe żony decydowały względy ambicjonalne. Zdaniem rozmówcy, żona podjęła decyzję o wyjeździe, mimo że sytuacja finansowa rodziny nie była szczególnie trudna. Kobieta chciała być współodpowiedzialną za ekonomiczne funkcjonowanie rodziny i chciała pracować. Wypowiedź jednej $\mathrm{z}$ badanych kobiet ukazuje podobny sposób odnoszenia się do pracy i roli wobec rodziny: „Miałam tak niskie poczucie wartości ze względu na brak pracy [...] Ja miałam poprzez wyjazd zarobić konkretne pieniądze dla małżeństwa. Zrobiłam to $\mathrm{z}$ myślą o rodzinie i małżeństwie, żeby nie tylko mąż był zobligowany do zarabiania" (28 K 30). Cytowana, młoda kobieta chciała być aktywna zawodowo i była silnie zorientowana na pracę. Zwłaszcza, że - jak sama podkreślała - wszyscy jej znajomi pracowali, robili karierę. Praca na migracji, zarobkowanie miało dać jej uznanie i pieniądze [Bjerke 2004:103].

Kobiety chciały przez wyjazd migracyjny zaspokoić nie tylko potrzeby materialne, ale także poznawcze, takie jak: nauka języka, możliwość bycia w innej kulturze, poznawanie nowych miejsc i ludzi. Oto wypowiedź zarejestrowana w trakcie wywiadu: „Chciałam sprawdzić się w innej kulturze. Zobaczyć jak to jest. Chciałam to poznać, sprawdzić. Mogłam też szkolić swój język” (33 K 27).

\section{Ocena pracy za granicą i warunków jej wykonywania}

Badane kobiety odnosiły się do swojej pracy wykonywanej za granicą w sposób niejednoznaczny. Jej różnorodność przez charakter przydzielanych zadań, miejsce zatrudnienia, warunki socjalno-bytowe w znacznym stopniu determinowały oceny kobiet. Badania ilościowe pokazały, że ogół kobiet ocenił swoją pracę jako: dobrze płatną $(M=4,24)^{2}$, dobrze zorganizowaną $(M=3,91)$, wykonywaną w dobrych warunkach socjalnych $(\mathrm{M}=3,62)$, w dobrej atmosferze

2 W badaniach zastosowano pięciostopniową skalę Likerta. (1 zdecydowanie nie, 2 raczej nie, 3 nie wiem, nie mam zdania, 4 raczej tak, 5 zdecydowanie tak. M oznacza średnią ocenę nadaną przez ogół badanych kobiet. Badano rozkład normalny. 
$(\mathrm{M}=3,62)$, w otoczeniu życzliwych ludzi $(\mathrm{M}=3,53)$. Gorzej badane odniosły się do takiego jej wymiaru, jak: zgodna z moimi kwalifikacjami $(M=2,59)$.

Trudno stwierdzić, na ile wypowiedzi tej zbiorowości, to swoiste strategie dowartościowania siebie i tego, co robiły. Zwłaszcza, że bardziej dogłębne wypowiedzi pozyskane podczas wywiadów i relacje z pamiętników ukazują pracę niektórych osób w innym świetle. Opisywano nie tylko warunki pracy, ale również socjalne zaplecze oferowane przez pracodawców. Oto fragment z listu migrantki dotyczący wyjątkowo złej organizacji pracy i miejsca noclegowego. Pracowałam od 6,00 do 21,00, a później musiałam jechać na rowerze 5 kilometrów. A w domu było nas 24 osoby. Do dyspozycji mieliśmy jedną lodówkę, jeden piec, dwa małe pokoje i salon z jedną kuchnią i jedną łazienką. Spaliśmy na podłodze, na materacach, kołdrach (List nr 4).

Warunki pracy, w jakich pracowały kobiety były mocno zróżnicowane. Od skrajnie negatywnych, które przedstawia jeden z fragmentów listu: „Praca trwała 12-14 godzin. Nikogo nie obchodziło, że jestem kobietą i ciągnięcie półtonowego wózka jest zbyt ciężkie (List nr 17); Każdy odpoczynek (napicie się, wyjście do ubikacji, czy zjedzenia śniadania) musiała być włączona pauza. Wszystko było na podczerwień i każdy nasz ruch, szef widział na komputerze. Raz zrobiłam błąd w pracy i za karę musiałam pracować 48 godzin bez spania” (List nr 4), po pozytywne: „co do organizacji pracy, to była bardzo dobra. Każdy wiedział, jakie są jego obowiązki i co ma zrobić. Zarobki też były dobre" (14 K 22). Rozmowa z cytowaną wyżej kobietą pokazała, że mimo dobrych warunków pracy niekomfortowy był dojazd do niej (kilkanaście kilometrów rowerem) i przede wszystkim mocno hierarchiczne relacje między pracownikami a bezpośrednimi przełożonymi. „Ci co znajdują się na stanowisku, czasem tylko o poziom wyżej, strasznie swoje stanowisko wykorzystywali. $\mathrm{Na}$ każdym kroku starają się pokazać swoją wyższość, to że są lepsi. A często jest tak, że mieszkają w tym samym domku lub mieszkaniu co inni” (14 K 22). Na taki dyskryminujący sposób myślenia pracodawców o swoich cudzoziemskich pracownikach zwracała uwagę inna migrantka. W jej odczuciu holenderscy pracodawcy „są mili, bo muszą tacy być, bo to są ich jakieś konwenanse, ale z drugiej strony Polacy czy też pracownicy z innych krajów są dla nich takimi ludźmi drugiej kategorii. Wyście tu przyjechali, żeby sadzić kwiatki, czy pakować drukarki, czy grzebać w śmieciach. A my jesteśmy o tyle lepsi, że nie musimy, po prostu nie musimy" (9 K 24). Kobieta zdaje się dostrzegać znaczenie dystansu władzy w miejscu pracy. Są nierówności między przełożonymi i podwładnymi. Rola tych ostatnich „sprowadza się do wykonywania poleceń przełożonych"[Hofstende, Hofstende, Minkow 2011: 84]. 
Dla wielu kobiet ważna była motywacja do pracy: „jeżeli masz dobre motywacje wtedy jest łatwiej w pracy" (4 K 25). Dobre motywacje to często odniesienie do otrzymywanych zarobków. $\mathrm{W}$ wielu relacjach dotyczących pracy pojawiły się stwierdzenia pokazujące, że praca za granicą stworzyła kobietom możliwości: bycia aktywną zawodowo, nawet gdy była to praca poniżej posiadanych kwalifikacji i umiejętności, zarobkowania, zdobywania nowych doświadczeń i poznawania nowych ludzi.

Świadomość pozytywnych aspektów pracy bywała „zmącona” faktem zagrożeń, negatywnych konsekwencji oraz czynników sprzyjających dysfunkcjonalności pracy. Jednym z czynników zakłócających proces pracy było postawienie jednostki w sytuacji trudnej. Często taka sytuacja miała miejsce już po przyjeździe do kraju migracji. Zmieniano zagwarantowane wcześniej miejsce pracy, jej charakter, rozdzielano osoby, które chciały razem pracować. Oto fragment takiej wypowiedzi: „Miałam jechać do «ciepłej piekarni», a na miejscu okazało się, że będziemy pracować w «chłodnej» masarni” (List nr 9). Autorka zwróciła uwagę na niewywiązywanie się z wcześniejszych zobowiązań osób odpowiedzialnych za samą rekrutację do pracy poza krajem. Tutaj warto zauważyć, że badane kobiety wskazywały na silne powiązania, sieci migracyjne sprzyjające wyjazdom i odpowiedzialne za zatrudnienie w kraju przyjmującym. Najczęściej korzystano z pomocy organizacyjnej : znajomych 43,95\%, biur pośrednictwa pracy za granicą $25,72 \%$, rodziny $18,25 \%$, w mniejszym stopniu z ogłoszeń prasowych $8,64 \%$, ofert zakładu pracy 6,33\%, stypendium 2,11\%. Oceniano również wyjazd jako „wyjazd «w ciemno» i poszukiwanie pracy dopiero po przyjeździe" $4,41 \%$.

Zdarzały się w pracy sytuacje trudne, bo wymagania i zakres pełnionych czynności były większe od tych, które wcześniej zostały ustalone. Problem często dotyczył kobiet mieszkających w domu swoich pracodawców i opiekujących się podopiecznymi i domem. Młoda kobieta tak to wspominała: „Moja codzienna praca wymagała dużego wysiłku, gdyż miałam zajmować się tylko dzieckiem, a w rzeczywistości musiałam zajmować się całym domem: sprzątanie, pranie, prasowanie, gotowanie. Poza tym dziecko wymagało karmienia, przewijania i spacerów. Jedynie wieczory zostawały mi na rozmowy do rodziny" (List nr 29). Autorka tego listu na migracji wykonuje czynności odnoszące się do zawodów o niskim statusie, w których nie ma większych możliwości awansu - osoby je wykonujące tkwią „przylepione” na najniższym poziomie” (pojęcie „lepkiej podłogi"), [Titkow 2003: 9].

Liczna rzesza migrujących kobiet podejmujących pracę $\mathrm{w}$ sektorze pracy domowej przyczynia się do nierówności w globalnej dystrybucji opieki i tworzenia się "globalnych łańcuchów opieki, czyli osobistych powiązań między 
osobami z różnych krajów, którzy podejmują się płatnej i nieodpłatnej opieki [Święćkowska 2010; Hochschild, Ehrenreich 2003]. Praca kobiet za granicą powoduje, że na czas ich migracji jest organizowana opieka w kraju pochodzenia. Efektem silnej migracji kobiet do krajów rozwiniętych, bogatszych jest pojawianie się nowej globalnej ekonomii usług i opieki, pochodzącej ze "stratyfikacji rynku pracy według płci kulturowej” [Rajman, Schannah-Gesser, Kemp 2003; za: Urbańska 2008: 81]. Ma miejsce urynkowienie pracy opiekuńczej oraz nierówny jej podział widoczny poprzez „drenaż opieki” czy wręcz „drenaż matek” oraz deficyt opieki w gospodarstwach domowych z krajów pochodzenia migrantek opisywany jako "globalny transfer kapitału macierzyńskiego" jako współczesny imperializm (love and care become the new gold), [Ehrenreich, Hochschild 2003]. Badane migrantki miały świadomość, że ich praca na migracji związana z opieką nad dziećmi, osobami starszymi, chorymi powoduje brak zaangażowania w to, co dzieje się w ich domach, w kraju. Taka sytuacja wpływa na pojawienie się i utrwalanie „opieki na odległość". Równocześnie badane kobiety czuły się usatysfakcjonowane tym, że zarobkują i jest opłacana praca, którą wcześniej niektóre z nich wykonywały w sposób nieodpłatny.

\section{Relacje z pracodawcami}

Dla wielu kobiet praca na emigracji była jedynym dochodem i być może dlatego potrafiły znieść skrajnie trudne warunki bytowe, rozstanie z domem. Wprawdzie w badaniach ilościowych respondentki uważały, że: czują się doceniane przez przełożonych $(26,7 \%)$ początkowo nie potrafiły radzić sobie z obowiązkami (16,7\%), czuły się zagubione (20,7\%). Niewiele dostrzegało, że miały przez cały czas trudności $z$ wykonywaniem pracy $(1,5 \%)$ i były dyskryminowane przez przełożonych (1,5\%). Uważały, że uczą się ciekawych umiejętności (16,7\%). Oto fragment wypowiedzi jednej z rozmówczyń: „Wiele się nauczyłam. Sama musiałam się nauczyć. Byłam jedynie na spotkaniu w Dusseldorfie dla doradców niemieckich i dla polskich firm. Trzy dni w języku niemieckim tłukli cały czas, a ja pisałam po polsku (bo nie umiałam po niemiecku) przez całe trzy dni i potem tłumaczyłam. Ja przecież to komputera nie znałam. Nauczyłam się programu księgowego" (29 K 60). Badania dotyczące problematyki wykluczenia technologicznego na rynku pracy świadczą, że technologie mogą być narzędziem wspierającym wykonywanie zadań w organizacji, ale też mogą ograniczać pracowników, zmuszając ich do nabycia nowych umiejętności i do zmiany dotychczasowych nawyków [Kincewicz, Żemigała 2013: 
220-223]. Dla sześćdziesięcioletniej kobiety, autorki wcześniejszej wypowiedzi, nowe wyzwania w pracy, nowe technologie nie były barierą w wykonywaniu pracy. Wręcz przeciwnie, stała się ona osobą wprowadzającą kolejnych adeptów w obszar pracy: „Rozkręcałam całą firmę od strony księgowości i wszelkich procedur. Potem szef nie miał stosownej osoby, która by to prowadziła" ( $29 \mathrm{~K}$ 60). Kobieta ta zdaje się burzyć stereotyp starszego pracownika pojawiający się w niektórych badaniach [Kasprzak-Choińska 2013: 318]. Nie cechował jej brak elastyczności, potrafiła poradzić sobie z problemem, jakim mogło być przyswojenie nowej wiedzy podczas szkoleń.

W badaniach jakościowych wypowiedzi charakteryzujące relacje kobiet z ich pracodawcami wskazywały na czynniki władzy i dominacji. Pracodawcy pozwalali sobie na zachowania, które uwłaczały badanym kobietom. Opisywane sytuacje świadczą, że czuły się one obrażane jako pracownice, kobiety i Polki. „Raz na przykład jedna Niemka powiedziała kiedyś, że było takie określenie schmutzige Polin (brudna Polka). Ja jej na to, to tak samo jakbym powiedziała, że Pani jest hitlerówką. Czy to prawda?, czy wolno uogólniać?. Tu są brudasy i tu są brudasy. Tu są mądrzy i głupi. Zrobiłam jej wykład i jest dystans, ale nie próbuje już" (30 K 60).

Podobna w charakterze jest wypowiedź innej kobiety. „Był u nas w pracy taki Helmut - tak go nazywałyśmy, który cały czas się darł, walił w blaty i krzyczał po niemiecku «wy polskie świnie». Taki prostak i cham. Nienawidziłam pracować na jego zmianie. Uważałam, że dobrze wykonuję swoją pracę" (27 K 51). W obu przypadkach mamy do czynienia z dyskryminacją o charakterze etnicznym [Smolski i in. 1999]. Kobiety odczuwały to traktowanie jako nieetyczne i nieprzystające do wykonywanej przez nie pracy i posiadanych możliwości: „bo ta staruszka jest zawistna, ja jestem nauczycielką. Ona z wykształcenia jest Housefrau i ja robię to, co ona kiedyś robiła i ją boli, że ona nigdy nie robiła tego co ja. Ona ma tę świadomość" (30 K 60). Inne badania świadczą, że mężczyźni bardziej pozytywnie niż kobiety postrzegają etyczność zachowań swego pracodawcy [Mc Daniel i in. 2001: 345-256]. Ale kobiety mogą mieć większe podstawy, aby tak się czuć.

Tylko niektóre migrantki oceniały pozytywnie swoje relacje ze zwierzchnikami: „Niemcy nauczyli mnie, by rozmawiać z ludźmi, prosząc nie rozkazywać. Może to kwestia losu. Przeznaczenie pozwoliło mi poznać takich a nie innych ludzi” (List nr 6). Autorka innego listu również była mile zaskoczona tym, co ją spotkało ze strony niemieckiego pracodawcy. „W pracy spodobało mi się zachowanie szefa. Każdy był traktowany tak samo. Nie czułam się gorsza tylko dlatego, że byłam sprzątaczką. Traktowaliśmy siebie jak kumpli, co w Polsce jest niespotykane" (List nr 2). 
Migrantki zdawały się godzić na ciężką, monotonną, fizyczną pracę, bo zdawały sobie sprawę, że wykonują ją tylko na jakiś czas. Pieniądze zarobione i wydawane na rzecz rodziny były rekompensatą za poniesiony wysiłek. Niektóre z nich wiedziały, że posiadają lepsze atrybuty niż ich pracodawcy, na przykład wykształcenie, umiejętności, kompetencje interakcyjne. Tego typu przeświadczenie pozwalało im przetrwać trudne chwile na migracji. Przeszkodą w pozyskaniu lepszej pracy bywał brak znajomości języka. Oto wypowiedź jednej z migrantek: „Wolałabym mieć inną pracę niż sprzątanie, ale mała znajomość, albo nikła języka niemieckiego mi to ograniczała. Więc pozostało mi tylko sprzątanie" (3 K 26).

Badane kobiety uczyły się relacji z pracodawcami, języka. Zdobywały nowe umiejętności nie tylko zawodowe, ale i społeczne. Próbowały utrzymywać aktywne społeczne interakcje z osobami z własnej grupy, jak i tej reprezentującej kraj, w którym przebywały. Nie zawsze im się to udawało, bo jak zauważa jedna z nich „większość robaczków takich, to tam cierpi. Zwyczajnie są z innej kultury i wchodzą w inną rzeczywistość. To nie jest tak, że się tam odnajdziesz" (3 K 26). Kobiety miały świadomość trudności związanych z wykonywaniem pracy, $\mathrm{z}$ warunkami, stosowanymi praktykami w obszarze pracy. Niektóre z nich uczciwie przyznawały się do tego rodzaju doświadczeń, tak jak to opisała w swoich wspomnieniach autorka jednego z listów, pamiętników: „Bardzo często spotykam się z osobami, które chwalą swoją pracę za granicą. Ja niestety do nich nie należę. Zdaję sobie sprawę, z tego że wiele osób wyjeżdża, bo muszą. I często zastanawiam czy ta pochwała pracy z dala od domu faktycznie wynika $\mathrm{z}$ tego, że jest tym ludziom tam tak dobrze, czy po prostu boją się lub wstydzą przyznać do tego, że jest im źle, a muszą to wszystko wytrzymywać, żeby utrzymać rodzinę" (List nr 9). Autorka listu pokazuje, że część kobiet mimo trudnych warunków w pracy, mimo aktów agresji czy dyskryminacji ze strony pracodawców może prezentować niespójne postawy. Włączane są mechanizmy obronne, ma miejsce obrona własnego ja, poczucia własnej wartości przez niedopuszczanie lub wypieranie ze świadomości tego, co rzeczywiście miało miejsce w obszarze pracy [Budrowska, Duch-Krzysztoszek, Titkow 2003:200]. Próby usprawiedliwienia pozostania w pracy dotyczyły takich dramatycznych sytuacji, o jakich pisała inna migrantka: „gospodarz domu zaczynał się dobierać do mnie. Musiałam się zamykać. Przychodziłam do kuchni, to mnie obmacywał, obcmokiwał, zaczynał się przytulać. Powiedziałam jemu tylko raz, żeby tego absolutnie nie robił, bo nie będę pracować, to powiedział: „to idź jeszcze ci nie zapłacę". No co miałam robić. Jak ja wiedziałam, że tu mam rachunki niezapłacone $\mathrm{z}$ kilku miesięcy. [...] Po dwóch miesiącach zrezygnowałam $\mathrm{z}$ tej pracy" (28 K 55). 


\section{Praca migracyjna a rodzina}

Na podstawie badań można stwierdzić, że wiele kobiet prezentowało mobilność rodzinną i jednym $\mathrm{z}$ bardzo ważnych powodów ich migracji było subiektywne poczucie odpowiedzialności za byt materialny rodziny. Rodzina, myślenie o rodzinie powodowało, że kobiety potrafiły znieść często trudne dla nich fizycznie warunki pracy. „Pracowałam, żeby pomóc dziecku, rodzinie. To mi pozwalało przetrwać. Teraz jak byłam płakałam, szczególnie na początku. Potem byłam bardzo taka wyciszona i potrafiłam tam siedzieć sobie w salonie i patrzeć na zdjęcie w telefonie mojego dziecka" (31 K 29).

Potrzeba zapewnienia właściwych warunków życia rodzinie stawała się przyczyną wyjazdów za granicę, szczególnie ważną, gdy matki czyniły to z myślą o dzieciach: „Chciałam zapewnić mojemu dziecku lepsze warunki do nauki, podróżowania” (13 K 32). Ta młoda kobieta chciała innego życia dla córki, bo jak wyznała w jej domu rodzinnym „nie było nikogo na kim można polegać, moja mama była alkoholiczką".

W trakcie pobytu za granicą migrantki koncentrowały się na swojej pracy, domu i bliskich, którzy pozostali w kraju. Oto relacja młodej małżonki: „Z początku myślałam o pracy, domu, znowu praca, dom, a później powiem szczerze o moim mężu. Pojawiła się tęsknota. Zmienił się mój stosunek do mojego męża, do dzieci. Mąż chciałby mieć już teraz dzidziusia, a ja mam właśnie takie mieszane uczucia. Chciałabym mieć teraz dzidziusia, ale chciałabym mieć stałą pracę. Mam, ale to jest dorywcze. Odsuwam w czasie, znaczy nie na długo. Rodzice chcieliby mieć wnuka, ale rozumieją będzie wtedy, kiedy będzie. Decyzja jest nasza” (26 K 27). Dzisiaj jest ona matką 2 dzieci i pracuje w Polsce. Ale kilka lat temu powiedziała, na temat swojego wyjazdu za granicę, że „ta praca w sumie była taka na krótki okres, żeby się dorobić, ale gdybym miała pracować jako sprzątaczka nie chciałabym. Nie po to skończyłam studia. No i moje ambicje" (26 K 27).

\section{Rozstanie z rodziną i sposoby jego odczuwania}

Kobiety $\mathrm{w}$ różny sposób opisywały to, co przeżywały $\mathrm{w}$ związku $\mathrm{z}$ rozstaniem się z rodziną. Najczęściej pojawiały się słowa opisujące takie emocje, jak tęsknota, żal, rozpacz, przygnębienie. Jedna z rozmówczyń, która pozostawiła małe dziecko, tak oceniała swoje rozstanie z rodziną: „To jest bardzo złe. To jest 
najgorsze, co może być. To jest po prostu chory układ zostawiając tutaj rodzinę, dziecko, wszystko. To jest nie do opisania" (13 K 32). Wyjechała - zostawiając w kraju 6-letnie dziecko i wyznała, że „to o nim najczęściej myślę, o moim małym dziecku, które poszło do szkoły. Ze względu, że mam małe dziecko i nie ma mi kto pomóc muszę być tutaj” ( $13 \mathrm{~K} 32$ ). Inna, młoda, bezdzietna kobieta zdawała się akceptować mobilność kobiet, ale takich, które jeszcze nie mają własnej rodziny: „jeżeli są to młode dziewczyny, które nie mają rodziny, obowiązków, to bardzo dobrze, że chcą wyjechać za granicę, zarobić pieniążki, rozwinąć się, poznać innych, ale jeżeli są to kobiety, które mają dzieci, męża, to już nie jest fajnie" (3 K 26).

Wyjazd spowodował, że migrantki bardzo tęskniły $(M=4,09)$. Niejednokrotnie mówiły o permanentnej tęsknocie, która ma miejsce w codzienności migracyjnej. Obawiały się, że mimo wielu wrażeń, jakie były udziałem ich życia migracyjnego wiele stracą z życia rodzinnego $(M=3,45)$, ponieważ bezpośrednio nie mogą uczestniczyć w życiu dzieci, wnuków i innych bliskich osób $(\mathrm{M}=3,30)$. Kobiety przywoływały różne rodzinne wydarzenia: urodziny dziecka, pierwszy dzień w szkole, chrzciny, ważne egzaminy. „O jej wynikach z matury dowiedziałam się w Niemczech. Bardzo bałam się o córkę i tęskniłam (29 K 60) i bardzo szczegółowo to opisywały w rozmowach i listach zwracając uwagę, że nikt nie zwróci tego czasu, który można było spędzić z bliskimi. Czasami nie warto było jechać” (List nr 9). Zwłaszcza, że jak opisywała to jedna z kobiet: „Brakowało mi poczucia bezpieczeństwa, które można mieć tylko w domu. Brakuje mi zwykłego przytulenia się, czasami tak bardzo, że aż boli” (List nr15).

Badane obawiały się, że podczas ich nieobecności zdarzy się coś złego w rodzinie $(M=3,77)$. Dramatyczne sytuacje pojawiały się w rodzinie pozostającej w kraju. Dotykały też migrantek. Często jedna i druga strona nie chcąc martwić się wzajemnie przemilczała to, co się zdarzało. Dopiero powrót był okazją do ujawnienia zaistniałych problemów.

Migrantki były świadome tego, co może dziać się z ich najbliższymi. Uważały, że podobnie jak one, ich rodzina przede wszystkim „ciągle tęskni” $(M=4,002)$, denerwuje się $(M=3,44)$. Jednak uważały, że bliscy mogli się już przyzwyczaić do $(M=3,36)$, ciesząc się że matki, żony mają pracę za granicą $(M=3,84)$ i uznając ich wyjazd zarobkowy za konieczność $(\mathrm{M}=3,21)$.

\section{Relacje w rodzinie}

W badaniach ilościowych kobiety stwierdzały, że niewiele zmieniło się w życiu rodziny w związku z ich wyjazdem za granicę. Uważały, że więzi rodzinne 
są bardzo silne (43\% wskazań) i silne (38\%). Wyjazd powodował, że najbardziej im brakowało dzieci (53,9\% zdecydowanie tak i 10,6\% raczej tak) i męża (52,4\% zdecydowanie tak, $15 \%$ raczej tak).

Czasami badanym kobietom trudno było wejść ponownie w rolę rodzica, małżonki. Tego typu sytuacje wywołane dłuższym pobytem za granicą mogły prowadzić do stresu i konfliktów. Oto relacja jednej z kobiet: „Oni przyzwyczajają się do stanu wolnego, a przyjazd raz w miesiącu na Wende to za mało, by rodzina mogła przetrwać. Odwiedziny w kraju stają się nie raz obowiązkiem, a nie przyjemnością" (List nr 15).Czasami dochodziło do rozstrzygnięć typu rozstanie, rozwód. Zarejestrowane opisy świadczą, że nie zawsze migracja sprzyja wierności wobec męża, partnera. Podobnie wygląda sytuacja w przypadku migrujących mężczyzn, o czym pisze autorka jednego z listów: „Byłam świadkiem, jak dziewczyna będąca w kraju wysłała «dzwonek» do swojego chłopaka, który był w Holandii. On jej oddzwonił, robiąc w tym czasie maślane oczy do współlokatorki. Dodam tylko, że to nie rzadkość" (List nr 15). Ta sama migrantka zauważa, że „ludzie, którzy przebywają za granicą ponad dwa lata i dłużej zwykle nie zdają egzaminu z wierności (choć są wyjątki)". Dlatego nie chce jeździć na tak długi czas, bo półtora roku jej migracji, jak sama to ocenia, to półtora roku z życia mojego dziecka i jest to strata nie do odrobienia

Wiele matek przeżywało podobne dylematy. I nie można, cytuję słowa młodej niezamężnej i bezdzietnej kobiety, „bezmyślnie krytykować i osądzać kobiet wychowujących dzieci, za to, że wyjeżdżają do pracy daleko od domu. Życie niestety pisze różne scenariusze i nigdy nie wiadomo, co nas może jeszcze spotkać" (List nr 9).

Wyjeżdżające matki starały się zorganizować opiekę dzieciom na czas swojej migracji. Badania pokazały, że opiekę i obowiązki domowe przejmowali: mężowie $24,38 \%$, rodzice $24,56 \%$, dzieci $24,37 \%$, dziadkowie $8,25 \%$, dalsza rodzina $19,2 \%$, rodzeństwo $8,83 \%$. Kobiety starały się utrzymywać kontakt z dziećmi, rodziną wykorzystując: telefon, skyp’a. W taki sposób między innymi opisywały rozmowy z dziećmi i mężem: „Najtrudniejsze jednak były dni, kiedy dzwoniłam do domu, kiedy słyszałam w słuchawce moje dziecko. Pytała «mamusiu ile jeszcze tam będziesz?». Mówiła «jestem grzeczna, trochę tęsknię, ale nie płaczę», a za chwilę mąż mówił, że krokodyle łzy spływają po jej buzi. Nigdy nie udało mi się wtedy zasnąć" (List nr 15). Kobiety, podobnie jak cytowana młoda matka miały wyrzuty sumienia, że w kraju pozostała rodzina, mąż, dzieci. Szczególnie trudna sytuacja była dla tych migrantek, które na wyjeździe opiekowały się innymi i ich gospodarstwem. Dlatego, kiedy przyjeżdżały do domu większość czasu przeznaczały na działania na rzecz domowników i go- 
spodarstwa. Jak opisywała jedna z nich: „Kiedy wracałam do domu musiałam wykonać generalne porządki. Mój mąż i córka nie zawsze to robili i nie zawsze dokładnie. Często im gotowałam to, co lubili najbardziej i przed samym powrotem do pracy za granicę zawsze coś zostawało przygotowane dla nich w lodówce, zamrażarce. Niewiele odpoczywałam. Odwiedzali nas znajomi” (32 K 55). Badania ilościowe pokazały, że po przyjeździe do domu migrantki najwięcej czasu przeznaczały na kontakt z dziećmi (zdecydowanie tak 21,3\%, raczej tak $38,40 \%)$ i na powrót do swojej pracy zawodowej (15,92\% zdecydowanie tak, $47,24 \%$ raczej tak).

\section{Zakończenie}

Obszar pracy, w jakim porusza się współczesny człowiek, wymaga od niego szeregu dyspozycji i cech umożliwiających pełną realizację jego osobowości oraz ukształtowania jako odpowiedzialnej osoby. Dla kobiet pracujących za granicą znaczące były również: wejście w inną kulturę, relacje $\mathrm{z}$ nowym środowiskiem pracowniczym, jak i pozapracowniczym, często poznawanie od podstaw nowego języka, ludzi, kraju. W przypadku niektórych kobiet praca migracyjna była pierwszą, jaką wykonywały. Powody: część kobiet wcześniej nie pracowała ze względu na młody wiek. Były i takie, które nie musiały tego czynić, bo pracował małżonek, partner. Niekorzystna zmiana ich dotychczasowej sytuacji ekonomicznej, rodzinnej, małżeńskiej wręcz wymusiła potrzebę podjęcia pracy zawodowej. Nie zawsze lokalny rynek był w stanie zaspokoić oczekiwania pracownicze i finansowe kobiet.

Badane kobiety musiały zmagać się nie tylko z określonymi umiejętnościami i zewnętrznymi czynnikami, ale także dysponować cechami świadczącymi o nastawieniu do pracy, takimi jak: odpowiedzialność, pracowitość, zaangażowanie, sumienność, uczciwość, lojalność, obowiązkowość. W wypowiedziach na temat swojej pracy ważną rangę nadały również takim cechom jak komunikatywność, otwartość, które były istotne w wykonywaniu pracy zawodowej, wręcz sprzyjające ogólnoludzkim relacjom, porozumieniu się i współistnieniu. Powstały obraz bliski jest temu, jaki kreowali studenci z Opolszczyzny. Uważali oni, że wyznacznikiem idealnego pracownika są głównie takie cechy i postawy, jak: pracowitość (68\%), uczciwość (48\%), obowiązkowość (44\%) oraz kreatywność (34\%), [Krasnodębska 2008a: 30]. Badania w środowisku studentów świadczyły, że dla młodych kobiet wiedza, nauka, umiejętności są istotnie statystycznie ważniejsze niż dla ich kolegów [Krasnodębska 2008a: 64-67]. Jed- 
nak może okazać się, że choć drzwi do wykształcenia zostały otwarte, „drzwi do rynku zatrudnienia i rynku pracy znowu zamknięto” [Beck 2004: 165].

Badania pozwoliły ukazać także sytuację rodziny migranckiej, bardzo silne emocje towarzyszące wszystkim członkom rodziny, związane $z$ wyjazdem matki do pracy za granicę, brak bezpośredniego udziału migrantek w życiu codziennym rodziny, jak i w wyjątkowych, ważnych momentach życiowych członków rodziny.

Praca kobiet na migracji pozwalała funkcjonować ich rodzinom. Część kobiet wyjeżdżała po to, aby zapewnić dzieciom lepszy standard życia, lepszą przyszłość. Podejmowały one decyzje o wyjeździe z przyczyn ekonomicznych, mając na uwadze niejednokrotnie właśnie dobro dziecka, zapewnienie sobie i rodzinie lepszych warunków życia: „Ja byłam zdruzgotana. Już tydzień przed wyjazdem co noc płakałam, bo tak strasznie nie chciałam wyjeżdżać. Zostawienie dwójki małych dzieci pod opieką babci było straszne... Ale z drugiej strony nie miałam wyjścia. Po prostu już nie miałam siły mieszkać z całą rodziną (moja rodzina, teściowie i szwagierka $\mathrm{z}$ mężem). Wolałam na chwilę zostawić moje dzieci niż dalej się męczyć. Po prostu musiałam" (46 K 36). Dla niektórych kobiet mobilność była określoną strategią macierzyńską i przekonaniem, że migracja może łączyć się z dobrze wypełnianymi rolami w rodzinie. Część pracujących matek traktowała swoje życie zawodowe jako poświęcenie dla dobra dziecka, rodziny. I tym samym praca poza domem dawała im poczucie własnej wartości, spełniania się nie dlatego, że jest się kimś innym niż matką, ale dlatego, że w inny sposób można wypełniać obowiązki matki [Dunn 2008: 172]. Wysiłek migracyjny podejmowały również babcie wobec swoich wnucząt.

\section{Bibliografia}

Beck U. (2004), Społeczeństwo ryzyka. W drodze do innej nowoczesności, Warszawa

Budzowska B., Duch-Krzysztoszek D., Titkow A. (2003), Dyskryminacja i jej wieloznaczności. Realne szanse kobiet, [w:] A. Titkow (red.), Szklany sufit. Bariery i ograniczenia karier kobiet, Warszawa

Dunn E. (2008), Prywatyzując Polskę. O bobofrutach, wielkim biznesie i restrukturyzacji pracy, Warszawa

Ehrenreich B., Hochschild A. R. (2003), Global Women. Nannies, Maids and Sex Workers in the New Economy, New York

Hofstende G., Hofstende G. J., Minkow M. (2011), Kultury i organizacje. Zaprogramowanie umystu, Warszawa 
Jończy R. (2010), Zagraniczne migracje zarobkowe z województwa opolskiego w latach 20082010 oraz ich wpływ na opolski rynek pracy i sfere fiskalna samorząów terytorialnych. Diagnoza i rekomendacje $w$ kontekście rozwoju regionu, Opole

Kasprzak-Choińska A. (2013), Dyskryminacja ze względu na wiek, [w:] K. Klincewicz (red.), Pracownicy o pracodawcach. Społeczna odpowiedzialność biznesu $w$ świetle badań jakościowych, Warszawa

Kincewicz K., Żemigała M. (2013), Technologie w miejscu pracy, [w:] K. Klincewicz (red.), Pracownicy o pracodawcach. Społeczna odpowiedzialność biznesu $w$ świetle badań jakościowych, Warszawa

Krasnodębska A. (2008a), Preferencje zawodowe studentów województwa opolskiego. Raport $z$ badań, Opole

Krasnodębska A. (2008b), Migracja zarobkowa a życie rodzinne kobiet z Opolszczyzny, [w:] E. Kozdrowicz, B. Walczak (red.), Migracja - Rodzina - Dziecko „Pedagogika Społeczna" nr 3 (29)

Krasnodębska A. (2009a), Badania oczekiwań pracodawców wobec potencjalnych pracowników, ich umiejętności i kwalifikacji w kontekście zjawiska migracji, Opole

Krasnodębska A. (2009b), Znaczenie zagranicznych migracji zarobkowych w ocenie kobiet Opolszczyzny, „Studia Socjologiczne” nr 4

Krasnodębska A. (2013a), Migracje i ich skutki w obszarze życia rodzinnego. Z doświadczeń opolskich migrantek, [w:] M. Lesińska, M. Okólski (red.), Współczesne polskie migracje: strategie - skutki społeczne - reakcja państwa, Warszawa

Krasnodębska A. (2013b), Role kobiety w ocenie opolskich migrantek. Spojrzenie matek i córek, „Studia Migracyjne-Przegląd Polonijny” z. 2

Mc Daniel C., Schoeps N., Lincourt J. (2001), Organizational ethics: Perceptions of employees by gender, "Journal of Business Ethics" nr 33

Okólski M. (2001), Mobilność przestrzenna z perspektywy koncepcji migracji niepełnej, [w:] E. Jaźwińska, M. Okólski (red.), Ludzie na huśtawce. Migracje między peryferiami Polski i Zachodu, Warszawa

Program Rozwoju Miasta Opola na lata 2007-2015 (aktualizacja) (2007), Załącznik do uchwały nr XIV/122/07 Rady Miasta Opola z dnia 28 czerwca 2007 roku

Rajman R., Schammah-Gesser S., Kemp A. (2003), International Migration, Domestic Work, and Care Work: Undocumented Latine Migrants in Israel, "Gender and Society" nr 5

Rauziński R., Szczygielski K. (2010), Czy kryzys demograficzno-społeczny na Ślasku Opolskim, [w:] Czy koniec Śląska jaki znamy, (red.) R. Radziński, T. Sołdra-Gwiżdż, R. Geisler, Opole

Sassen S. (2001), The Global City, New York. London, Tokyo. 2 nd Editio Princeton, NY, Princeton University

Schimanek T. (2006), Sytuacja osób powyżej 50-tego roku życia na rynku pracy oraz rola organizacji pozarządowych świadczacych usługi rynku pracy skierowane do tych osób, Warszawa

Slany K. (2008), Co to znaczy być migrantka, [w:] K. Slany (red.), Migracje kobiet. Perspektywa wielowymiarowa, Kraków

Smolski R., Smolski H., Stadtmuller E., (1999), Słownik encyklopedyczny: Edukacja obywatelska, Wrocław

Sztanderska U. (2006), Działalność organizacji pozarządowych świadczacych usługi na rynku pracy skierowane do kobiet, Warszawa 
Święćkowska T. (2010), Migracja i gender z perspektywy pracy domowej i opiekuńczej, Warszawa Urbańska S. (2008), Transnarodowość jako perspektywa ujęcia macierzyństwa w warunkach migracji, [w:] K. Slany (red.), Migracje kobiet. Perspektywa wielowymiarowa, Kraków 


\section{SUMMARY}

\section{Relations between Opole Female Work Migrants, Their Employers and Families}

The text has been based on the quality research which was carried out in 2007 and 2008 in the Opole region migrants' environment (60 interviews and 30 letters - diaries). The diaries were describing emotions, feelings and thoughts of women working abroad. Women were going abroad to improve living conditions of their families. The outcome of multifaceted quantity research contains the descriptions of women's emotional states. The research is based on two groups of women: migrating: 357 females, and non-migrating: 164 females. Female migrants were aware of difficulties connected with their working abroad (parting with the family and hard, sometimes monotonous, work). However, they could become independent financially and active professionally. The state of being employed could change their social position, their way of thinking and their social roles. For some women mobility was a specific maternal strategy and the way to fulfill their roles in a family.

Keywords:

female migration, family 